University of Nebraska - Lincoln

DigitalCommons@University of Nebraska - Lincoln

\title{
Spatial and Temporal Variation of Energy and Carbon Fluxes in Central lowa
}

\author{
J. L. Hatfield \\ National Soil Tilth Lab, jerry.hatfield@ars.usda.gov \\ J. H. Prueger \\ National Soil Tilth Lab \\ W. P. Kustas \\ Hyrdology and Remote Sensing Lab
}

Follow this and additional works at: https://digitalcommons.unl.edu/usdaarsfacpub

Hatfield, J. L.; Prueger, J. H.; and Kustas, W. P., "Spatial and Temporal Variation of Energy and Carbon Fluxes in Central lowa" (2007). Publications from USDA-ARS / UNL Faculty. 1345.

https://digitalcommons.unl.edu/usdaarsfacpub/1345

This Article is brought to you for free and open access by the U.S. Department of Agriculture: Agricultural Research Service, Lincoln, Nebraska at DigitalCommons@University of Nebraska - Lincoln. It has been accepted for inclusion in Publications from USDA-ARS / UNL Faculty by an authorized administrator of DigitalCommons@University of Nebraska - Lincoln. 


\title{
Spatial and Temporal Variation of Energy and Carbon Fluxes in Central Iowa
}

\author{
J. L. Hatfield,* J. H. Prueger, and W. P. Kustas
}

\begin{abstract}
Energy balance and $\mathrm{CO}_{2}$ exchange of agricultural crops has been investigated through limited field studies because of the expense of the monitoring equipment and availability of fields to place equipment. Quantifying the spatial and temporal variation in the energy balance and $\mathrm{CO}_{2}$ dynamics over crop canopies will improve regional-scale estimates of water and $C$ fluxes. A study was conducted in central Iowa during 2002 as part of the Soil Moisture Experiment to evaluate soil moisture energy exchange across an intensive corn (Zea mays $\mathbf{L}$.) and soybean [Glycine max (L.) Merr.] production area near Ames, IA

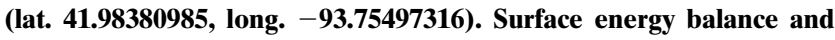
$\mathrm{CO}_{2}$ flux stations were placed in 12 corn and soybean fields across different soils and landscapes in and around the Walnut Creek watershed. Variability among fields was induced by three factors. Within a day, variations among fields were due to the presence of cumulus cloud formation in the afternoon. Short-term differences across days among the fields were due to variation in the spatial pattern of rainfall events causing differential drying. Throughout the season, differences among fields were due to soil water availability, which affected crop growth and ground cover. Differences in early season ground cover were correlated with energy balance $(r=0.80)$. During the growing season, latent heat and $\mathrm{CO}_{2}$ uptake were closely related $(r=0.85)$. Characterization of the spatial distribution of energy balance and $\mathrm{CO}_{2}$ uptake in an intensive cropping region provides guidance on the confidence that can be placed in interpreting single-site measurements.
\end{abstract}

$\mathrm{E}$ XCHANGES of energy and $\mathrm{CO}_{2}$ from the soil and canopy surface in the Corn Belt are influenced by changes in land cover and cropping practices. Houghton (1999) estimated $124 \mathrm{Pg} \mathrm{C}\left(1\right.$ petagram $\left.=10^{15} \mathrm{~g}\right)$ have been added to the atmosphere as a result of land use changes between 1850 and 1990, of which $13 \%$ has been from conversion of midlatitude grasslands to cultivated cropland. One of the most intense areas for this conversion is the Upper Midwest corn-soybean region of the USA, comprised of $>60$ million ha representing $60 \%$ of cultivated cropland in the USA. There are important implications for surface energy balance and $\mathrm{CO}_{2}$ uptake associated with major land use conversions. In the Upper Midwest region, native prairie grasslands have been replaced with corn and soybean crops. This conversion is important because of the configuration of the rows planted on the soil surface and the reduction in the length of the year that the crop provides cover on the soil surface. Latent heat flux $(L E)$ exchange processes

J.L. Hatfield and J.H. Prueger, National Soil Tilth Lab,, 2150 Pammel Drive, Ames, IA 50011; and W.P. Kustas, Hyrdology and Remote Sensing Lab., Beltsville, MD 20705. Mention of trade names or commercial products in this article is solely for the purpose of providing specific information and does not imply recommendation or endorsement by the USDA. Received 25 Apr. 2005. *Corresponding author (hatfield@nstl.gov).

Published in Agron. J. 99:285-296 (2007).

Special Submissions

doi:10.2134/agronj2005.0116S

(c) American Society of Agronomy

677 S. Segoe Rd., Madison, WI 53711 USA between the surface and boundary layer of the atmosphere for a native prairie were altered when prairie was transformed from a continuously covered grass surface to a corn and soybean production system in which the soil surface annually transitions from bare soil to full canopy cover to crop residue and finally to bare soil again. The exposed soil surface during the non-growing portion of a year as well as during the emerging crop phase represents an important energy exchange period (Ham et al., 1991) that responds to varying soil surface conditions. Surface heterogeneity induced by early row crop development (exposed soil with changing crop canopy) contributes to the challenge of quantifying and understanding energy exchange processes from bare soil and emerging crops (Luxmoore et al., 1973; Hatfield, 1989; Ham et al., 1991). Byre et al. (2000) reported that hydrologic budgets were significantly altered for Wisconsin prairies after conversion to a corn-soybean agroecosystem. Although cumulative evapotranspiration (ET) was comparable between the two crops there was a different temporal distribution of ET between corn and prairie fields (Byre et al., 2000).

Climate and landscape were found to be two critical factors affecting the water balance in Australia (Farmer et al., 2003). These findings are similar to observations by Kustas and Albertson (2003), who used a large eddy simulation model to quantify spatial variations of sensible and latent heat fluxes. They found that spatial variation was present across landscapes and that the mechanisms for these differences needed to be understood to help improve regional-scale model predictions. Small and Kure (2003) suggested that coupling between soil moisture and the radiation budget would create significant differences across regions. Walker et al. (2001) observed that the spatial variation of soil moisture was critical to understanding the water balance of a watershed in eastern Australia. Lyons and Halldin (2004) observed that surface heterogeneity was a major factor in the spatial variation of sensible and latent heat exchanges in southern Sweden.

Estimating the surface energy balance components and understanding the complex processes of energy and mass exchange from land surfaces and the boundary layer of the atmosphere is critical to many applications in meteorology and hydrology. Measurement of mass, energy, and $\mathrm{CO}_{2}$ fluxes between the terrestrial surface and the atmosphere was the major focus of this effort. Assuming advection is negligible, the surface energy fluxes are related by

$$
Q^{*}+G+H+L E=0
$$

Abbreviations: $\mathrm{CO}_{2}$ flux, carbon dioxide uptake; DOY, day of the year; EC, eddy covariance; LAI, leaf area index; SMEX02, Soil Moisture Experiment 2002. 
where $Q^{*}$ is net radiation $\left(\mathrm{W} \mathrm{m}^{-2}\right), G$ is soil heat flux $\left(\mathrm{W} \mathrm{m}{ }^{-2}\right), H$ is sensible heat flux $\left(\mathrm{W} \mathrm{m}^{-2}\right)$, and $L E$ is latent heat flux $\left(\mathrm{W} \mathrm{m}^{-2}\right)$, where $L$ is the latent heat of vaporization of water $\left(\mathrm{J} \mathrm{kg}^{-1}\right.$, relatively constant $)$ and $E$ is the evapotranspiration rate $\left(\mathrm{kg} \mathrm{m}^{-2} \mathrm{~s}^{-1}\right)$. The variation of the energy balance with time and space has not been well characterized or quantified for particular ecoregions like the Corn Belt. In central Iowa, Hatfield and Prueger (2001) found large variations in water use within a production-scale cornfield ( $35 \mathrm{ha}$ ) that ranged between 300 and $600 \mathrm{~mm}$ during the growing season. Spatial analysis of these fluxes has not been examined in detail, although there is evidence that the degree of variation can be significant compared with the mean fluxes.

Spatial variation has also been observed in $\mathrm{CO}_{2}$ fluxes. Soegaard et al. (2003) observed differences among crops and fields within a study area in western Denmark. They used a weighted field value of $\mathrm{CO}_{2}$ to determine the regional estimate of $\mathrm{CO}_{2}$ uptake. Arora (2003) observed that accurate predictions of $\mathrm{CO}_{2}$ fluxes for winter wheat (Triticum aestivum L.) were only achieved when energy fluxes appropriate for the area were incorporated into the model. Meyers and Hollinger (2004) found that closure of the energy balance was possible when canopy storage terms were incorporated into the analysis of the energy balance, which decreased the scatter of the partitioning of $Q^{*}$ into the remaining energy components. Baker and Griffis (2005) observed that eddy covariance systems provided adequate tools for the assessment of the $\mathrm{C}$ balance of corn and soybean production systems. These recent studies have not addressed spatial variation but serve to show that further refinement in our understanding of the energy balance would improve our ability to quantify the impacts of changing management practices on energy and $\mathrm{CO}_{2}$ fluxes.

Variation of energy balance and $\mathrm{CO}_{2}$ fluxes within intensive agricultural areas has not been well documented. Many questions remain about the spatial and temporal dynamics of these fluxes across an agricultural watershed that, if better understood, could provide improved insights into regional-scale energy and $\mathrm{CO}_{2}$ flux exchange. An intensive field study involving multiple towers and fields in central Iowa was conducted in the summer of 2002 as part of the Soil Moisture Experiment (SMEX02). The objective of this study was to quantify the spatial and temporal variations in the energy balance and $\mathrm{CO}_{2}$ fluxes across a watershed under intensive corn and soybean production.

\section{MATERIALS AND METHODS}

\section{Study Site}

The study was conducted in the Walnut Creek watershed in central Iowa, located $5 \mathrm{~km}$ south of Ames $\left(41^{\circ} 75^{\prime} \mathrm{N}, 93^{\circ} 41^{\prime} \mathrm{W}\right)$, as part of a long-term monitoring effort to assess interactions of crop water use, $\mathrm{CO}_{2}$ uptake, and yield as a function of $\mathrm{N}$ management for corn and soybean. Walnut Creek watershed is a 5100-ha watershed of intensive corn and soybean production fields ranging in size from 40 to $160 \mathrm{ha}$. These two crops

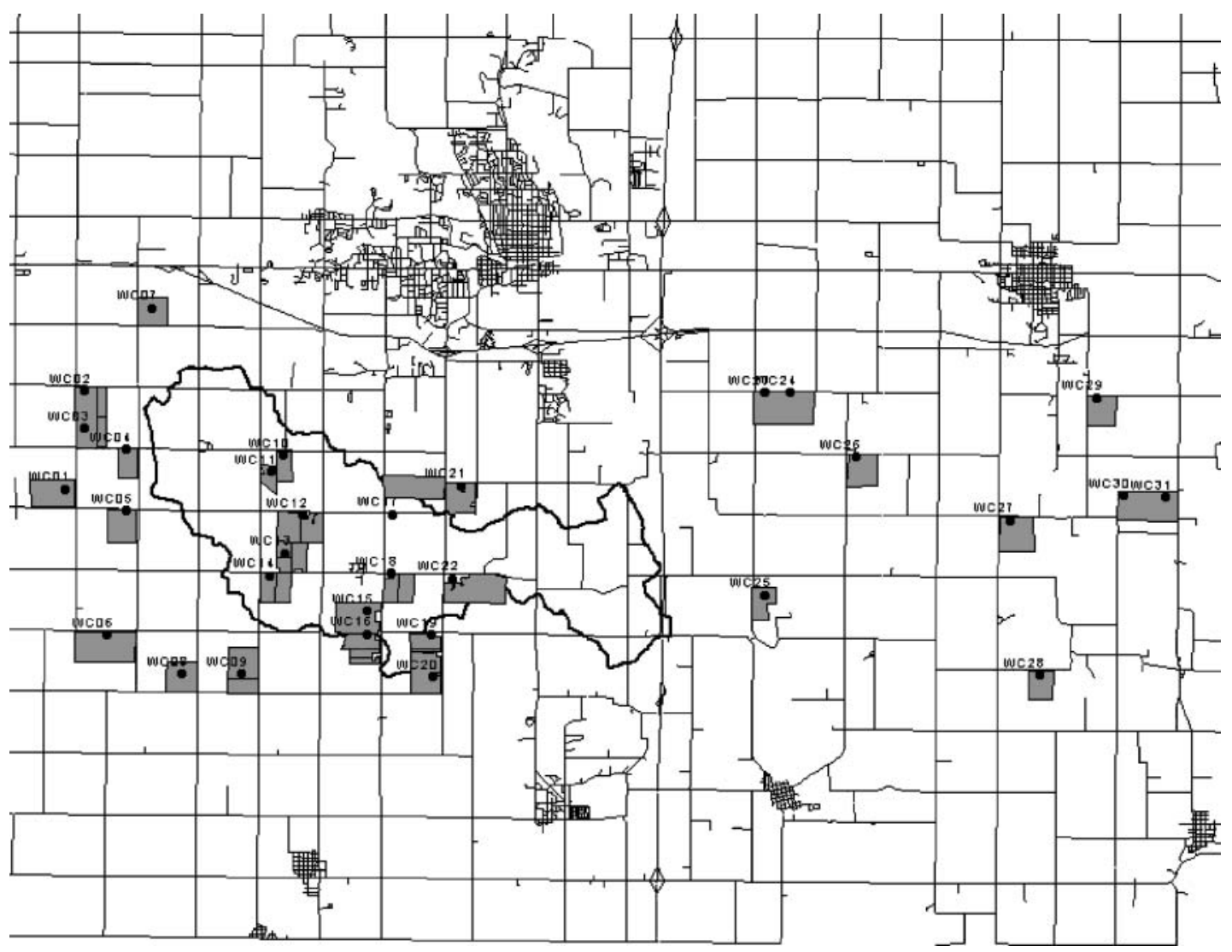

Fig. 1. Location of the monitoring towers within the Walnut Creek watershed and surrounding area and position within the corn and soybean fields. 
Table 1. Site Identification, crop, soil type, and fraction of field represented by site location for the SMACEX sites in 2002.

\begin{tabular}{|c|c|c|c|c|}
\hline Site & Crop & Soil type & $\begin{array}{l}\text { Fraction } \\
\text { of field }\end{array}$ & $\begin{array}{c}\text { Soil water- } \\
\text { holding capacity } \\
\text { (for upper } 1 \mathrm{~m} \text { ) }\end{array}$ \\
\hline & & & & $\mathbf{m m}$ \\
\hline 3 & soybean & $\begin{array}{l}\text { Clarion: fine-loamy, mixed, } \\
\text { mesic Typic Hapludoll }\end{array}$ & 0.30 & 212 \\
\hline 6 & corn & $\begin{array}{l}\text { Clarion: fine-loamy, mixed, } \\
\text { mesic Typic Hapludolls }\end{array}$ & 0.24 & 212 \\
\hline 10 & corn & $\begin{array}{l}\text { Nicollet: fine-loamy, mixed, } \\
\text { mesic Aquic Hapludoll }\end{array}$ & 0.16 & 220 \\
\hline 11 & soybean & $\begin{array}{l}\text { Harps: fine-loamy, mesic } \\
\text { Typic Calciaquoll }\end{array}$ & 0.18 & 221 \\
\hline 13 & soybean & $\begin{array}{l}\text { Harps: fine-loamy, mesic } \\
\text { Typic Calciaquoll }\end{array}$ & 0.12 & 221 \\
\hline 14 & soybean & $\begin{array}{l}\text { Clarion: fine-loamy, mixed, } \\
\text { mesic Typic Hapludoll }\end{array}$ & 0.24 & 212 \\
\hline 25 & corn & $\begin{array}{l}\text { Spillville: fine-loamy, mixed, } \\
\text { mesic Cumulic Hapludoll }\end{array}$ & 0.41 & 214 \\
\hline 33 & corn & $\begin{array}{l}\text { Nicollet: fine-loamy, mixed, } \\
\text { mesic Aquic Hapludoll }\end{array}$ & 0.10 & 220 \\
\hline 151 & corn & $\begin{array}{l}\text { Clarion: fine-loamy, mixed, } \\
\text { mesic Typic Hapludoll }\end{array}$ & 0.34 & 212 \\
\hline 152 & corn & $\begin{array}{l}\text { Canisteo: fine-loamy, mixed } \\
\text { (calcareous), mesic } \\
\text { Typic Haplaquoll }\end{array}$ & 0.33 & 209 \\
\hline 161 & soybean & $\begin{array}{l}\text { Clarion: fine-loamy, mixed, } \\
\text { mesic Typic Hapludoll }\end{array}$ & 0.35 & 212 \\
\hline 162 & soybean & $\begin{array}{l}\text { Clarion: fine-loamy, mixed, } \\
\text { mesic Typic Hapludoll }\end{array}$ & 0.35 & 212 \\
\hline
\end{tabular}

occupy approximately $85 \%$ of the land area in the watershed. The topography of the watershed and surrounding areas are characterized by flat to gently rolling terrain with elevations in the watershed ranging from 265 to $363 \mathrm{~m}$, with the lowest elevations situated on the eastern end of the watershed where Walnut Creek drains. Details of production, tillage, and nutrient management systems within the watershed are described in Hatfield et al. (1999a).

In 2002, a remote sensing soil moisture experiment (SMEX02) was conducted in the Walnut Creek watershed. The energy balance study was conducted as part of a Soil Moisture and Energy Exchange (SMACEX) portion of SMEX02, as described by Kustas et al. (2005). This study provided the opportunity to place 12 eddy covariance (EC) stations across the watershed to measure and evaluate the spatial and temporal variation among fluxes across typical corn and soybean production fields in the Upper Midwest region. These stations were in operation during the intensive measurement period of the remote sensing campaign (Kustas et al., 2003) and continued to record measurements until late August
2002. Sites of the EC stations are shown in Fig. 1. For each site in the field, the soil type was extracted from the soil map from Boone or Story county (Soil Conservation Service, 1981, 1984). Eddy covariance sites were located in a range of soil types typical of central Iowa and, in most fields, the location represented $>0.20$ of the total area in the field. The primary difference among the soils was the soil water-holding capacity in the upper $1 \mathrm{~m}$ of the soil profile (Table 1). This provided an excellent opportunity to measure and evaluate not only differences in turbulent fluxes between corn and soybean but also the spatial and temporal variability of turbulent flux exchange of $\mathrm{CO}_{2}$ and $\mathrm{H}_{2} \mathrm{O}$ across the agricultural landscape.

\section{Instrumentation}

Turbulent fluxes of sensible and latent heat $(H$ and $L E)$ and $\mathrm{CO}_{2}$ were measured using the EC approach in 12 fields, six in corn and six in soybean (Table 2). Each EC system was comprised of a three-dimensional sonic anemometer (CSAT3, Campbell Scientific, Logan, UT) and a fast-response water vapor $\left(\mathrm{H}_{2} \mathrm{O}\right)$ and $\mathrm{CO}_{2}$ density open-path infrared gas analyzer (LI7500, LI-COR, Lincoln, NE). At all sites, EC instrumentation was maintained on $10-\mathrm{m}$ towers at approximately $2 h$ (where $h=$ canopy height in meters) above the surface. The sampling frequency for the EC systems was $20 \mathrm{~Hz}$ with all of the high-frequency data stored onto PCMCIA cards. Before and after the experiment, a comparison of the EC systems was conducted over a grass surface. The results of this comparison are described in Meek et al. (2005).

Ancillary meteorological instrumentation on each tower included a four-component net radiometer (CNR-1, Kipp \& Zonen, Saskatoon, SK), soil heat flux plates (REBS HFT-3) $\mathrm{Cu}-\mathrm{Co}$ Type $\mathrm{T}$ soil thermocouples, two high-precision infrared radiometric temperature sensors (IRT, $15^{\circ}$ field of view, Apogee Instruments, Logan, UT) and an air temperature $\left(T_{\mathrm{a}}\right)$-relative humidity $(\mathrm{RH})$ sensor (Vaisala HMP-35, Campbell Scientific, Logan, UT). The net radiometer, air temperaturehumidity sensor, and one IRT ( $45^{\circ}$ angle of view) sensor were mounted $4.5 \mathrm{~m}$ above ground level (AGL). The second IRT sensor was located $0.15 \mathrm{~m}$ AGL with a nadir view providing continuous radiometric temperatures of the soil surface. Four soil heat flux plates were placed $0.06 \mathrm{~m}$ below the soil, two within the plant row and two within the interrow space. Pairs of soil thermocouples were placed 0.02 and $0.04 \mathrm{~m}$ below the surface and above each soil heat flux plate. Soil water content in the top $0.1 \mathrm{~m}$ at each site was measured with Delta-T ThetaProbes (Delta-T Devices, Cambridge, UK) and together with soil temperature data were used to compute the storage

Table 2. Field location, crop, row direction and spacing, and instrumentation for the SMACEX sites in 2002.

\begin{tabular}{|c|c|c|c|c|c|c|c|}
\hline Field & Crop $\dagger$ & Row direction $\nleftarrow$ & Row spacing & LI7500 or KH20 & CNR1 or REBS & Latitude & Longitude \\
\hline & \multicolumn{5}{|c|}{$\mathbf{m}$} & \multicolumn{2}{|c|}{$\longrightarrow^{\circ}$} \\
\hline WC03 & $\mathbf{S}$ & $\mathbf{N}$ & 0.38 & LI7500 & CNR1 & 41.98380985 & -93.75497316 \\
\hline WC06 & $\mathbf{C}$ & $\mathbf{N}$ & 0.76 & LI7500 & CNR1 & 41.93289579 & -93.75331502 \\
\hline WC10 & $\mathbf{S}$ & $\mathbf{X}$ & 0.05 & КH20 & REBS & 41.97659611 & -93.69109344 \\
\hline WC11 & $\mathbf{C}$ & $\mathbf{N}$ & 0.76 & КН20 & REBS & 41.9746 & -93.69369 \\
\hline WC13 & $\mathbf{S}$ & $\mathbf{N}$ & 0.76 & KH20 & REBS & 41.95215301 & -93.68766257 \\
\hline WC14 & $\mathbf{S}$ & $\mathbf{X}$ & 0.05 & LI7500 & REBS & 41.94598467 & -93.69622139 \\
\hline WC15_1 & $\mathbf{C}$ & $\mathbf{E}$ & 0.76 & LI7500 & REBS & $\mathbf{4 1 . 9 3 7 8 1 8 2 4}$ & -93.6631318 \\
\hline WC15_2 & $\mathbf{C}$ & $\mathbf{E}$ & 0.76 & LI7500 & CNR1 & 41.93781542 & -93.66469965 \\
\hline WC16_1 & $\mathbf{S}$ & $\mathbf{E}$ & 0.25 & LI7500 & REBS & 41.93414103 & -93.66270304 \\
\hline WC16_2 & $\mathbf{S}$ & $\mathbf{E}$ & 0.25 & LI7500 & CNR1 & 41.93548368 & -93.66405839 \\
\hline WC23 & $\mathbf{S}$ & $\mathbf{E}$ & 0.20 & КН20 & REBS & 41.99245328 & $-\mathbf{9 3 . 5 3 5 8 1 8 0 4}$ \\
\hline WC24 & $\mathbf{C}$ & $\mathbf{N}$ & 0.76 & LI7500 & CNR1 & 41.99291298 & -93.52857874 \\
\hline WC25 & $\mathbf{C}$ & $\mathbf{E}$ & 0.76 & LI7500 & CNR1 & 41.94226863 & $-\mathbf{9 3 . 5 3 9 3 7 4 2 8}$ \\
\hline WC33 & C & $\mathbf{E}$ & 0.76 & LI7500 & CNR1 & 41.975341 & -93.64431294 \\
\hline
\end{tabular}

$\dagger \mathbf{C}$, corn; S, soybean.

$+N$, north-south; $E$, east-west; $X$, flex coil. 
component of the soil heat flux. The sampling frequency for the ancillary instrumentation was $0.1 \mathrm{~Hz}(10 \mathrm{~s})$ with measured values stored as 10 -min averages.

Observations of ground cover and measurements of leaf area index (LAI) and plant biomass were conducted in each field. The sampling procedures were performed near the energy balance sites in each of the fields, and are reported in Anderson et al. (2004).

\section{Data Screening and Processing}

The $20-\mathrm{Hz}$ time-series data were first conditioned by despiking for anomalies of the critical parameters of the three wind components (downwind $u$, crosswind $v$, and vertical $w$ ), the sonic temperature $\left(T_{\mathrm{s}}\right)$ and the signals for water vapor and $\mathrm{CO}_{2}$. Data were then passed through a low-frequency filter and used to compute 30-min averages of $H, L E, \mathrm{CO}_{2}$, and all pertinent micrometeorological parameters and statistics. Additionally, a two-dimensional coordinate rotation and corrections for air density fluctuation effects were applied to the scalar fluxes (Baldocchi, 1988; Webb et al., 1980). Half-hour data were screened for consistency and obvious data outliers for all of the parameters observed during the study. This was accomplished by plotting the data for each day and examining the calculated fluxes. This process was completed for each tower and any suspect data points resulted in the entire time period being deleted from the overall record. Data capture for this experiment was $>95 \%$.

\section{RESULTS AND DISCUSSION}

Spatial variation in the energy balance components among fields are affected by changes in ground cover and plant growth differences. Variation in precipitation amounts within the growing season can affect the availability of water for evaporation either through water for surface evaporation or crop water use. Changes in the spatial patterns of energy exchanges and $\mathrm{CO}_{2}$ fluxes throughout the growing season are important to quantifying regional-scale variation in crop production systems.

\section{Variation in Ground Cover}

Variation in ground cover among the corn fields during the intensive observation period was minimal (Fig. 2). All fields had $>0.5$ ground cover when the ob-

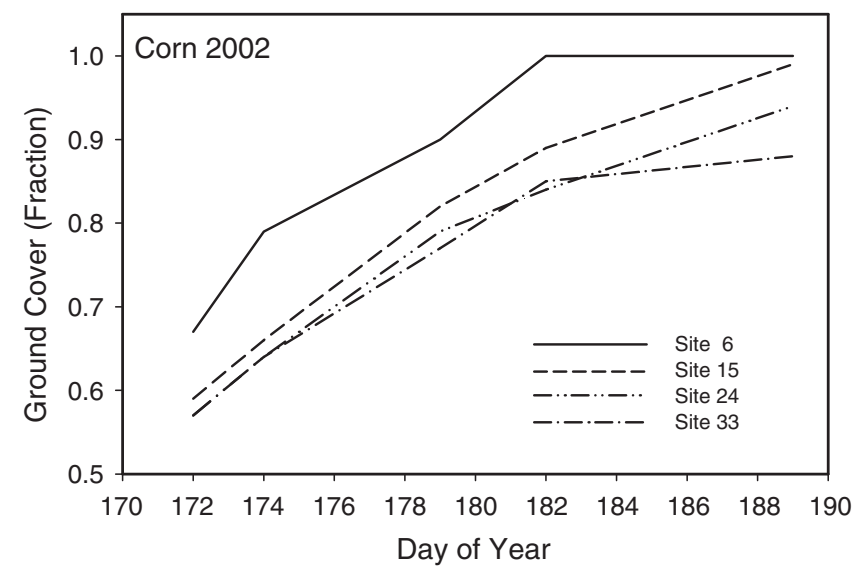

Fig. 2. Ground cover for the corn fields with intensive energy balance in the SMACEX study for the period from Day of the Year (DOY) 172 to 189 in 2002.

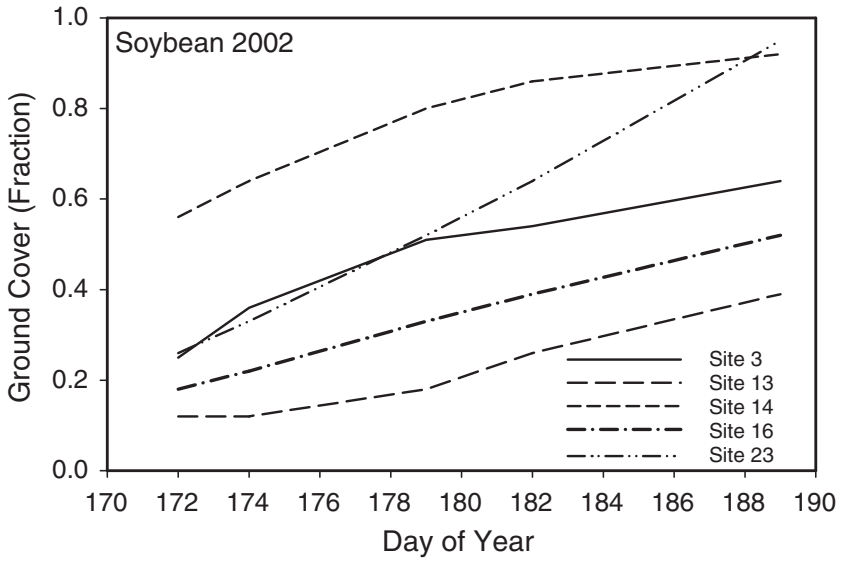

Fig. 3. Ground cover for the soybean fields with intensive energy balance in the SMACEX study for the period from Day of the Year (DOY) 172 to 189 in 2002.

servations commenced and Site 6 had the most rapid rate of growth, achieving complete ground cover by DOY 180. Only Site 33 was not greater than 0.9 ground cover by the end of the intensive study period (Fig. 2).

Variation in ground cover among soybean fields was considerably more evident than in the corn fields. Initial ground cover across the sites ranged from 0.12 to 0.56 (Fig. 3). Differences were due to the planting configuration of the soybean fields, with the greater ground cover in fields that were planted with a flexcoil unit that produced a random placement of the seed into the soil (Table 2). Other fields had more defined rows and less of ground cover early in the season. At the end of the intensive study period, the range in ground cover was from 0.39 to 0.95 (Fig. 3).

Variations in total biomass, LAI, and height at the end of the intensive period were evident among the fields for corn and soybean (Table 3). Biomass varied among the corn canopies, although there was little difference in canopy height (Table 3). A similar response was noted among the soybean fields, with significant field-to-field differences in biomass and LAI and small differences in crop height (Table 3).

\section{Variation in Precipitation}

The initial part of the experiment had no precipitation events. The first rain event occurred on DOY 185 (4 July 2002) and was unevenly distributed across the

Table 3. Aboveground dry biomass, leaf area index, and height of the crops on Day of the Year (DOY) 189 for different sites in the SMACEX energy balance study in 2002.

\begin{tabular}{lcccc}
\hline Crop & Site & Biomass & LAI & Height \\
\hline \multirow{3}{*}{ Corn } & & $\mathrm{g} \mathrm{m}^{-2}$ & $\mathbf{m}^{2} \mathbf{m}^{-2}$ & $\mathbf{m}$ \\
& $\mathbf{6}$ & $\mathbf{9 0 1}$ & 4.52 & $\mathbf{1 . 8 4}$ \\
& $\mathbf{1 5}$ & 822 & 4.77 & $\mathbf{2 . 0 0}$ \\
& $\mathbf{2 4}$ & 776 & 4.64 & $\mathbf{1 . 8 4}$ \\
Soybean & $\mathbf{2 5}$ & $\mathbf{6 1 1}$ & $\mathbf{3 . 4 1}$ & $\mathbf{1 . 5 5}$ \\
& $\mathbf{3 3}$ & $\mathbf{6 8 5}$ & $\mathbf{3 . 8 0}$ & $\mathbf{1 . 7 9}$ \\
& $\mathbf{3}$ & $\mathbf{1 1 6}$ & $\mathbf{2 . 8 4}$ & $\mathbf{0 . 3 4}$ \\
& $\mathbf{1 3}$ & $\mathbf{1 3 9}$ & $\mathbf{1 . 7 0}$ & $\mathbf{0 . 4 1}$ \\
& 14 & $\mathbf{3 4 3}$ & $\mathbf{3 . 2 2}$ & $\mathbf{0 . 4 8}$ \\
& 16 & $\mathbf{1 0 9}$ & $\mathbf{1 . 0 3}$ & $\mathbf{0 . 3 3}$ \\
& $\mathbf{2 3}$ & $\mathbf{1 5 6}$ & $\mathbf{3 . 0 7}$ & $\mathbf{0 . 4 2}$ \\
\hline
\end{tabular}




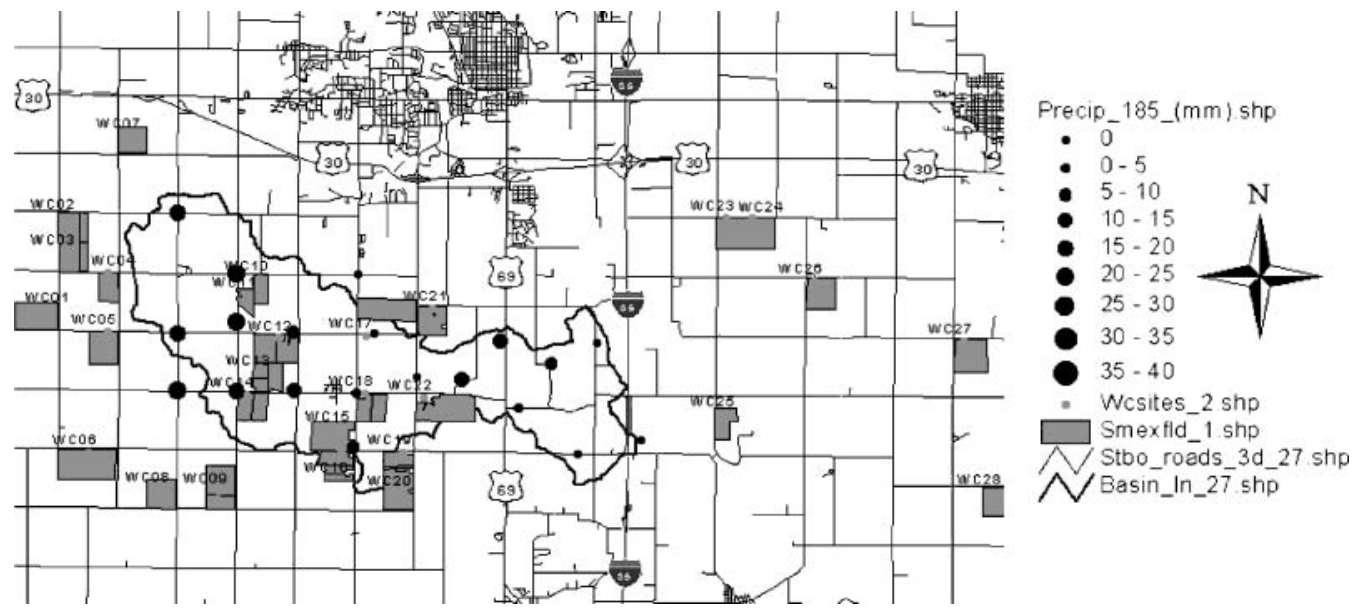

Fig. 4. Distribution of precipitation across the eddy covariance sites in Walnut Creek watershed on 4 July 2002 (Day of the Year [DOY] 185).

study area (Fig. 4). Precipitation decreased in the eastern part of the watershed (Fig. 4). Precipitation is a major driving variable in the energy balance in rainfed areas because of the impact on the evaporation component (Eq. [1]). Variation in precipitation throughout the study period in 2002 created a unique opportunity to evaluate the effects of spatial differences on the energy balance components.

Seasonal totals of precipitation across the watershed did not exhibit significant differences. Precipitation patterns shown in Fig. 4 and 5 are typical of most spring and summer seasons in the Walnut Creek watershed, as shown by Hatfield et al. (1999b). The spatial variation in the distribution of precipitation across the watershed can affect the energy balance because of the changes in surface soil water content. The initial differences in precipitation persisted throughout the study period (Fig. 5).

\section{Seasonal Energy Balance Changes}

Changes in the energy balance components occurred in each field during the first $20 \mathrm{~d}$ of the experiment. Complete 24-h periods averaged for all corn and soybean fields are shown for $Q^{*}$ and $G$, while only the daytime averages are shown for $L E, H$, and $\mathrm{CO}_{2}$ fluxes because of issues related to obtaining reliable nighttime flux values (Fig. 6 and 7). In this sequence of days, there was only one precipitation event so plant growth was dependent on stored water in the soil profile. During the observation period, there were minor changes in $Q^{*}$ values for both corn and soybean fields (Fig. 6a and 7a). There were no extremely cloudy days during this portion of the study, resulting in a condition of mostly clear skies during the early growing season as evidenced by the consistent $Q^{*}$ values among days (Fig. 6a and 7a).

Soil heat fluxes showed a consistent decline during this period of the study as a result of the increasing vegetative cover. Peak $G$ values for the corn fields were $100 \mathrm{~W} \mathrm{~m}^{-2}$ at the beginning of the study period, declining to a peak value of nearly $70 \mathrm{~W} \mathrm{~m}^{-2}$ at the end of the study period (Fig. 6b). Ground cover values for the corn fields at the beginning of this period exceeded 0.5 (Fig. 2), compared with soybean, which averaged 0.3 (Fig. 3). This difference in ground cover in soybean fields was evident in $G$ values that approached $150 \mathrm{~W} \mathrm{~m}^{-2}$ on DOY 171 and declined to $<100 \mathrm{~W} \mathrm{~m}^{-2}$ by DOY 181 , when the fractional ground cover was nearly 0.5 (Fig. 7b).

Latent heat and $H$ fluxes during this period changed in magnitude as the crop developed (Fig. 6c, 6d, 7c, and $7 \mathrm{~d})$. In the soybean fields, maximum values were

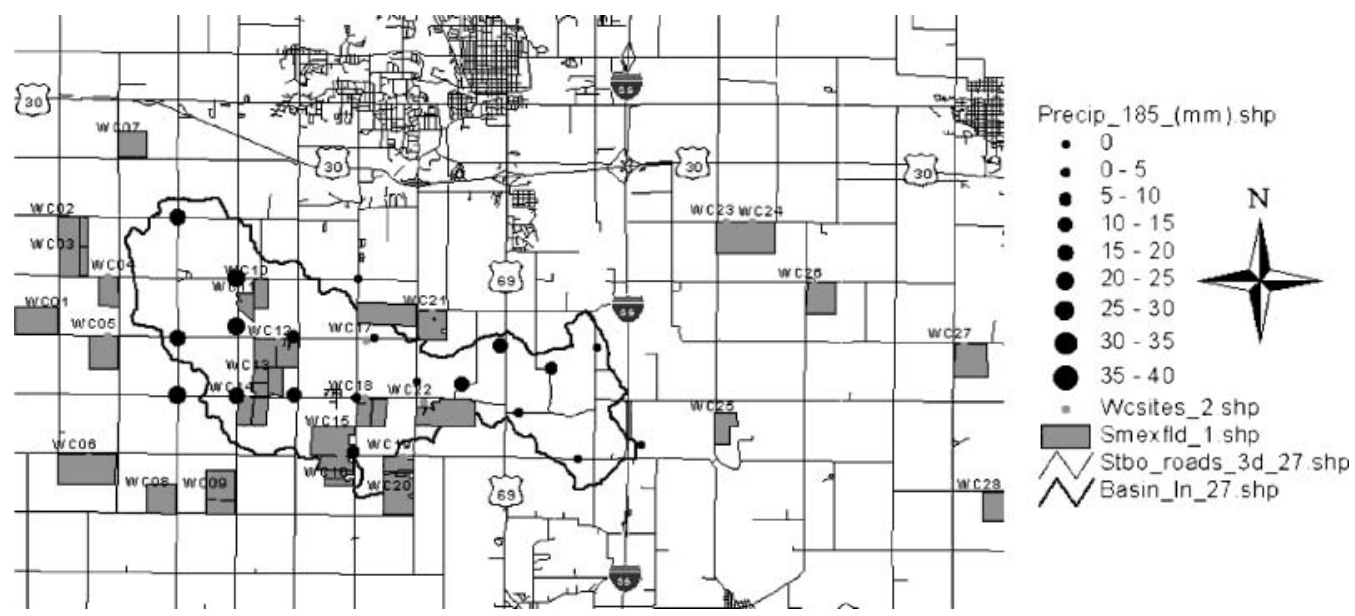

Fig. 5. Distribution of cumulative precipitation for the study period in 2002 for the eddy covariance sites in Walnut Creek watershed. 

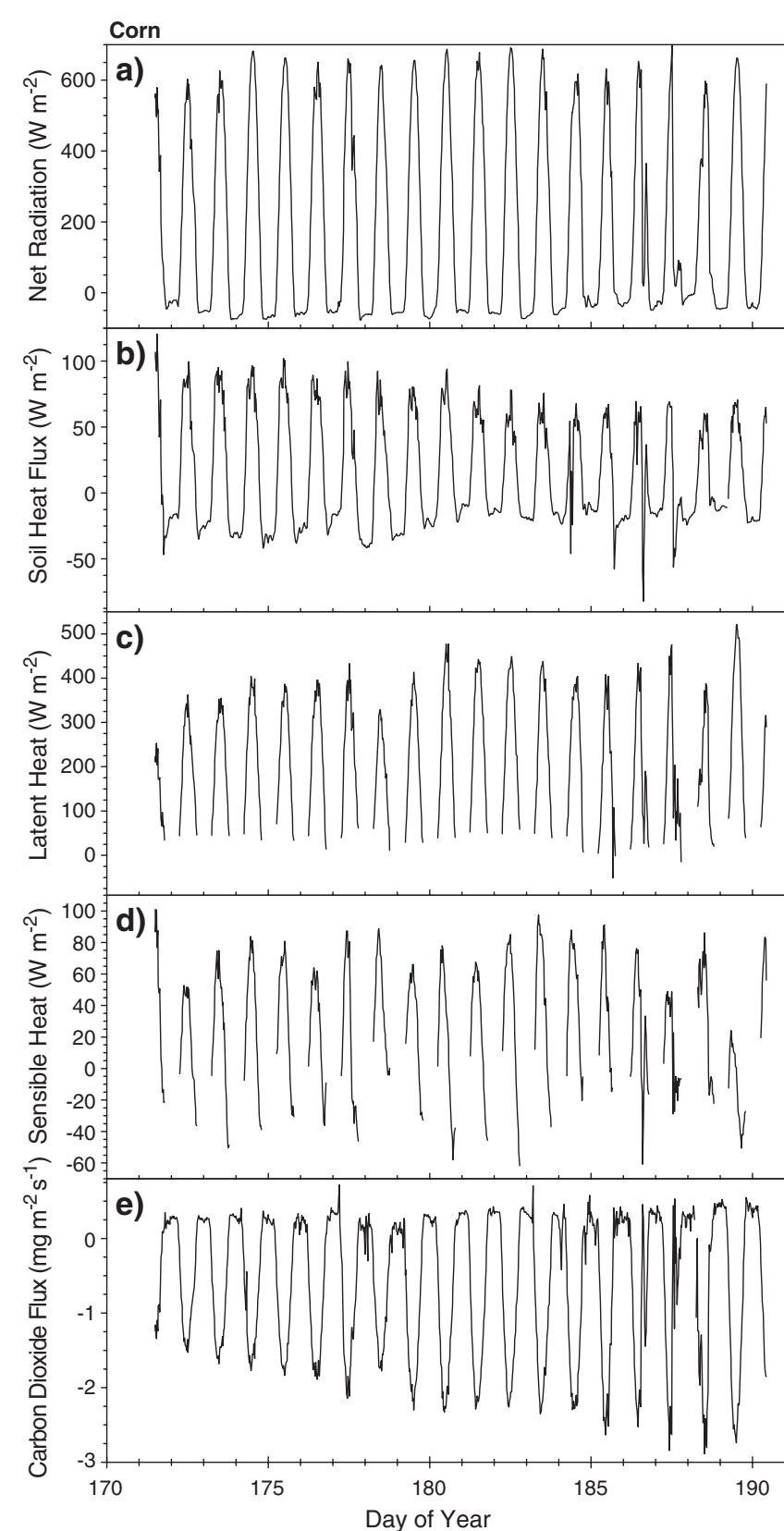

Fig. 6. Average daily fluxes of (a) net radiation, (b) soil heat flux, (c) latent heat, (d) sensible heat, (e) and $\mathrm{CO}_{2}$ fluxes for Days of the Year (DOY) 171 to 190 for corn fields in central Iowa.

$300 \mathrm{~W} \mathrm{~m}^{-2}$ until the last $4 \mathrm{~d}$ of the intensive period, when the daytime maximums began to approach $500 \mathrm{~W} \mathrm{~m}^{-2}$ (Fig. 7c). This large increase in $L E$ fluxes and the concurrent decrease in $H$ was related to the rainfall event on DOY 185. Sensible heat fluxes for the corn fields showed daytime maximums of $50 \mathrm{~W} \mathrm{~m}^{-2}$ and did not vary by more than $20 \mathrm{~W} \mathrm{~m}^{-2}$ during the intensive study period (Fig. 6d). Latent heat fluxes in the corn fields were larger than those in the soybean fields (Fig. $6 \mathrm{c}$ vs. 7c) with the sensible heat fluxes lower in the corn than the soybean (Fig. 6d vs. 7d). The larger amount of ground cover and LAI for the corn fields contributed to the larger $L E$ and consequently lower $H$ fluxes. In comparison, $H$ fluxes for the soybean fields reached
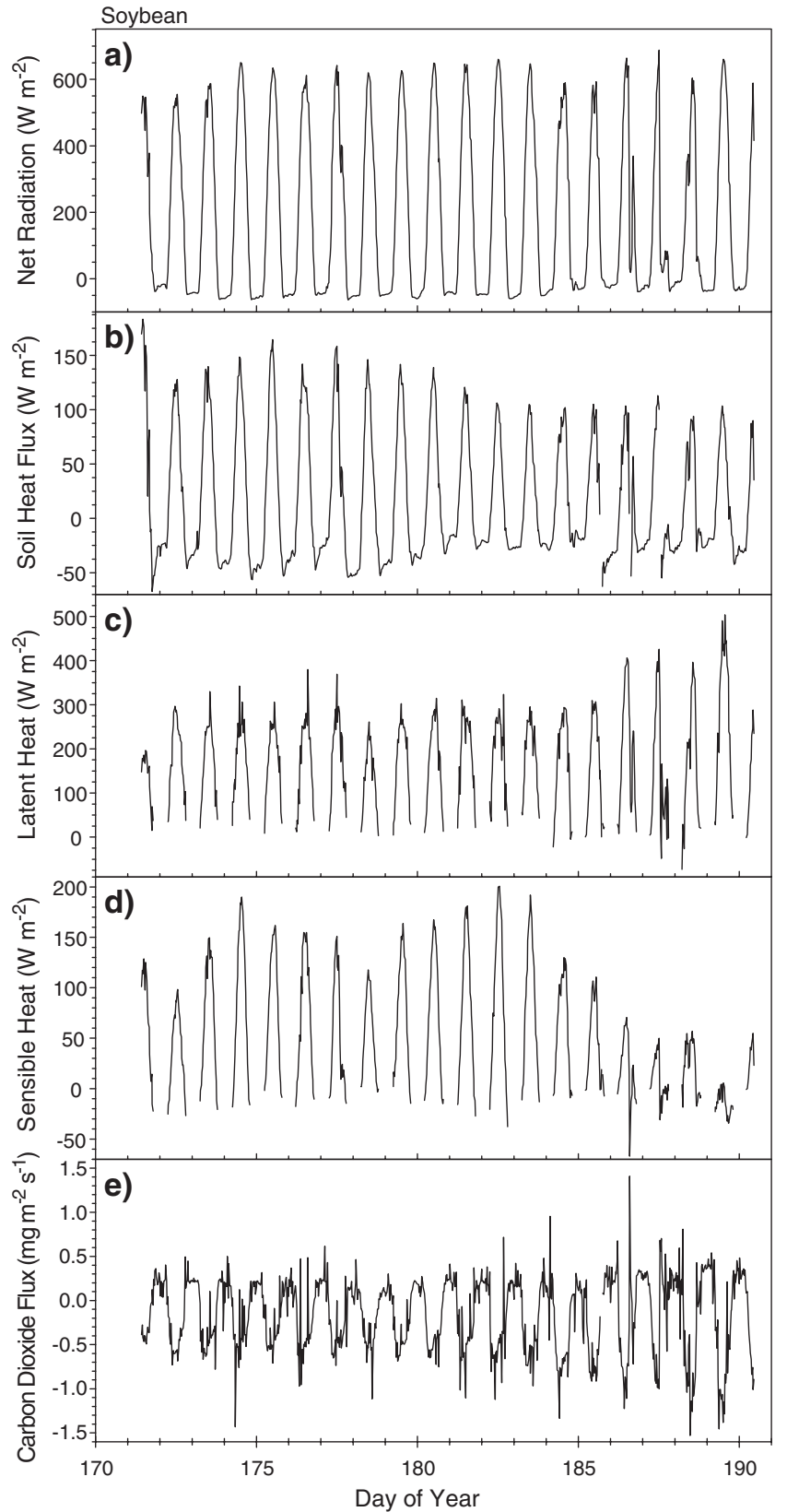

Fig. 7. Average daily fluxes of (a) net radiation, (b) soil heat flux, (c) latent heat, (d) sensible heat, and (e) $\mathrm{CO}_{2}$ fluxes for Days of the Year (DOY) 171 to 190 for soybean fields in central Iowa.

maximum values of $200 \mathrm{~W} \mathrm{~m}^{-2}$ during the study period and did not begin to decline until the rainfall event on DOY 185, when the canopies began to cover more than 0.5 of the soil surface (Fig. 3 and $7 d$ ). After this time, the daytime maximums were similar to those of the corn canopies.

Fluxes of $\mathrm{CO}_{2}$ showed the largest change during the study period over both canopies; $\mathrm{CO}_{2}$ daytime fluxes steadily increased in response to photosynthetic uptake as the total biomass increased (Fig. 6e and 7e). For the corn canopies, there was a linear increase in the daytime maximum during the $20 \mathrm{~d}$, with peak values increasing from 1.5 to $2.5 \mathrm{mg} \mathrm{m}^{-2} \mathrm{~s}^{-1}$ (Fig. 6e). Nighttime $\mathrm{CO}_{2}$ fluxes for both crops remained relatively constant dur- 
ing the intensive study period (Fig. 6e and 7e). A similar trend was observed for the soybean canopies, with maximum $\mathrm{CO}_{2}$ fluxes increasing from $0.5 \mathrm{mg} \mathrm{m}^{-2} \mathrm{~s}^{-1}$ at the beginning of the study period to $1.2 \mathrm{mg} \mathrm{m}^{-2} \mathrm{~s}^{-1}$ at the end (Fig. 7e). Increases in $\mathrm{CO}_{2}$ fluxes were closely coupled with $L E$ fluxes during the intensive study period (corn, $r=0.87$; soybean, $r=0.82$ ), as expected with the increased canopy biomass and LAI.

\section{Diurnal Variation in Energy Balance Parameters}

Daytime fluxes (defined as $Q^{*}>100 \mathrm{~W} \mathrm{~m}^{-2}$, which avoids the transitional morning and nighttime periods characterized by calm neutral conditions) of mass and energy were evaluated for each site for each 30-min period. The averages and deviations from the average for each corn and soybean site were computed for the period from DOY 171 through 190. Variation among the sites throughout the daytime period for all of the energy balance parameters was greater than the estimated variance determined from the co-location study (Meek et al., 2005). Only selected days are shown for both corn and soybean because the fields showed a consistent deviation from the mean throughout the study period (Fig. 8-11). Soil heat flux $(G)$ and sensible heat $(H)$ show the largest variation among the sites, in part due to the fact that the fraction of these two fluxes $\left(G / Q^{*}\right.$ or $H /$ $\left.Q^{*}\right)$ were approximately 0.20 and differences among fields induced by either soil surface conditions or crop growth results in a large amount of variation from the average. For example, on DOY 172 there was a nearly clear sky throughout the day and adequate water for evaporation, with a midday $H$ value of $60 \mathrm{~W} \mathrm{~m}^{-2}$ and range in deviations $\pm 20 \mathrm{~W} \mathrm{~m}^{-2}$ (Fig. 8d). An examination of $G$ for this same period shows a midday value of nearly $100 \mathrm{~W} \mathrm{~m}^{-2}$ and a deviation of $\pm 30 \mathrm{~W} \mathrm{~m}^{-2}$. These deviations are similar to those for $L E$ (Fig. 8c). Values for the soybean fields for this same day showed that the values for $L E, H$, and $G$ were nearly equal and the amount of variation among the fields was the same for all these components. One factor that could be responsible for this is the difference in ground cover

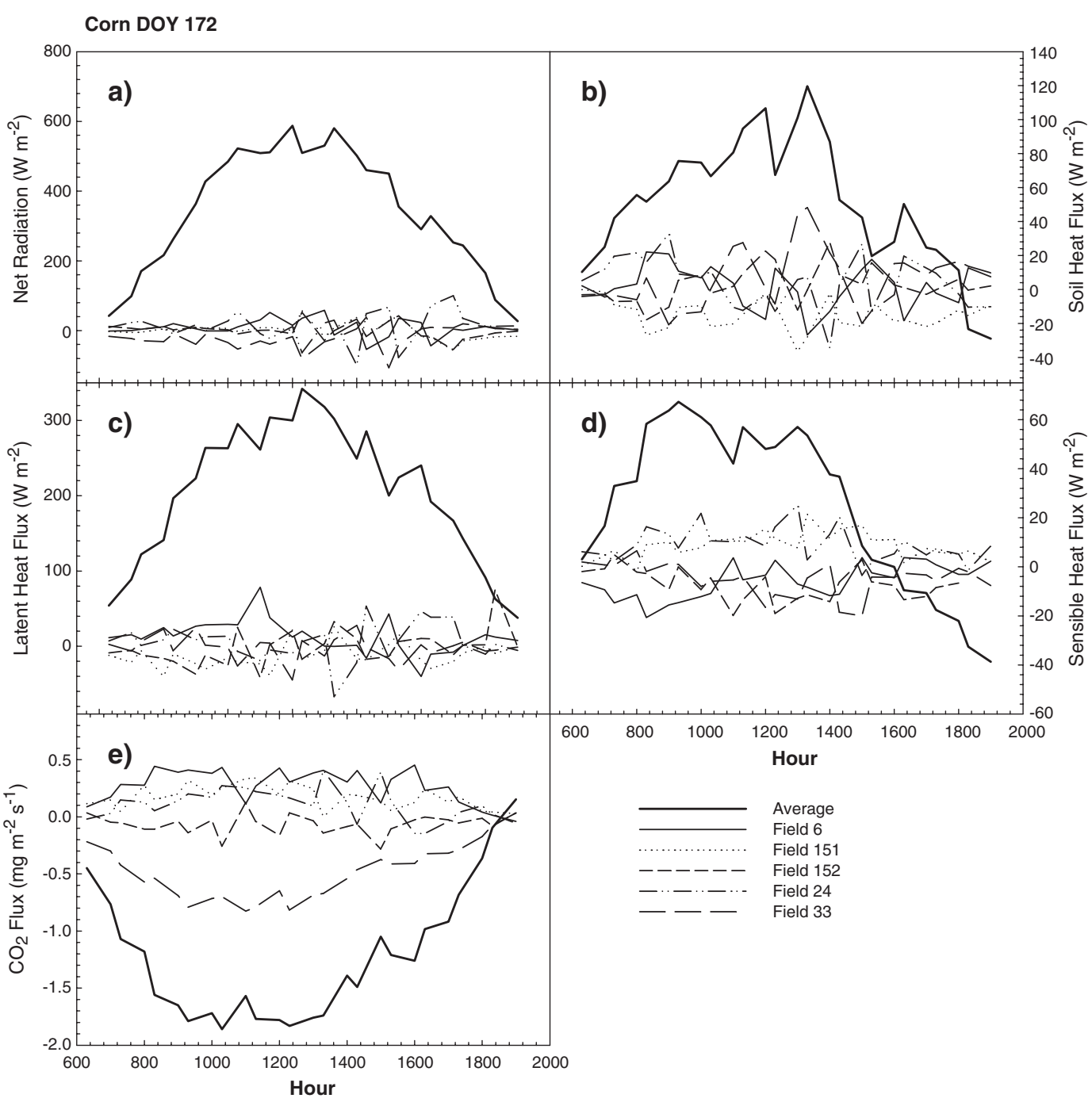

Fig. 8. Diurnal variation of average (a) net radiation, (b) soil heat flux, (c) latent heat, (d) sensible heat, and (e) $\mathrm{CO}_{2}$ fluxes and deviations of each field site from the mean across the corn fields in central Iowa monitored on Day of the Year (DOY) 172 in 2002. 


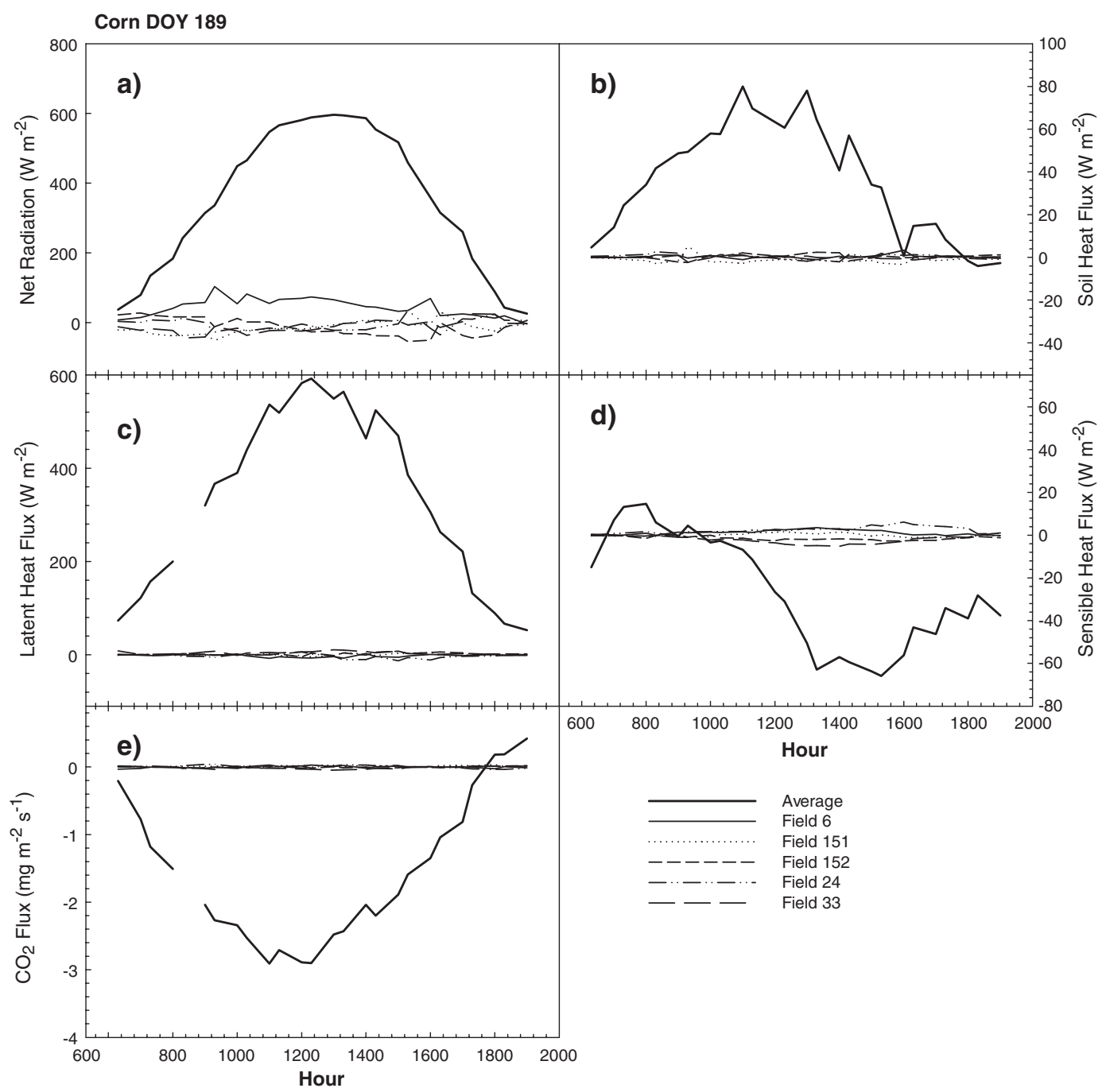

Fig. 9. Diurnal variation of average (a) net radiation, (b) soil heat flux, (c) latent heat, (d) sensible heat, and (e) $\mathrm{CO}_{2}$ fluxes and deviations of each field site from the mean across the corn fields in central Iowa monitored on Day of the Year (DOY) 189 in 2002.

between the corn and soybean fields. The $G / Q^{*}$ ratio relative to the fraction of ground cover showed a significant negative correlation of -0.69 for the corn fields and -0.74 for the soybean fields. Sites with more ground cover showed less variation from average values throughout the day (Fig. 8b, 9b, 10b, and 11b). Later in the study period (DOY 189) under clear sky conditions, variation was minimal among sites because of adequate soil water for $L E$ where $L E / Q^{*}$ was nearly 1.0 for the corn fields and 0.80 for the soybean fields (Fig. 9 and 11).

Variation in $Q^{*}$ among sites across days was dependent on cloud cover for each day. This area is dominated by cumulus clouds during the summer period and cloud cover is typically not uniformly distributed across the study area nor throughout a day. This is evident in the $2 \mathrm{~d}$ from both crops (Fig. 8a, 9a, 10a, and 11a). The patterns of variation among the sites were not uniform throughout the day, e.g., on DOY 172 in both the corn and soybean fields the variation increased in the afternoon when clouds became more prevalent and variable. In the morning, and throughout the day when the sky was clear, there was smaller variation, as shown for DOY 189 for both crops (Fig. 9a and 11a). Although there was consistency in the $Q^{*}$ values for the clear periods, there was still a large variation in the other fluxes. This observation was confirmed by examining the daily patterns in incoming solar radiation observed from two meteorological stations located within the study that showed differences in half-hourly fluxes during many afternoon periods.

Latent heat and sensible heat fluxes for these $2 \mathrm{~d}$ were typical of the early portion of the growing season. The $L E$ fluxes increased from less than half of $Q^{*}$ on DOY 172 to $>0.9 Q^{*}$ on DOY 189 for the corn canopies (Fig. 8c and 10c). Variation among the fields for $G, L E$, $\mathrm{H}$, and $\mathrm{CO}_{2}$ fluxes for the period immediately following the rainfall event was lower than before the rainfall. In the corn fields following the rainfall event on DOY 185 , the correlation between the variation among fields for $L E$ and the precipitation was 0.89 . In the soybean fields, this response was not as large because the leaf area and ground cover were not as large as the corn canopies (Table 3); however, the correlation of the varia- 


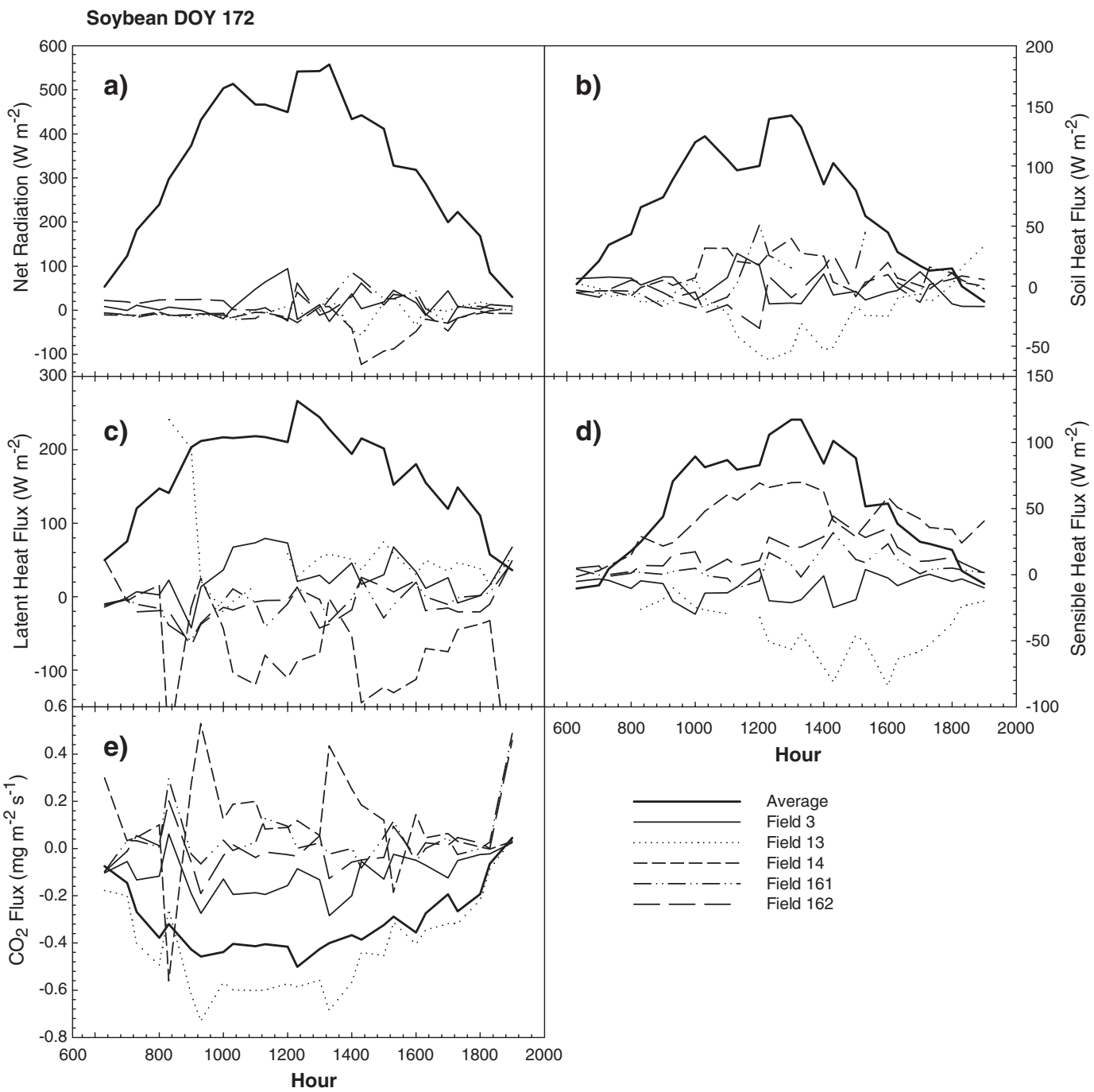

Fig. 10. Diurnal variation of average (a) net radiation, (b) soil heat flux, (c) latent heat, (d) sensible heat, and (e) $\mathrm{CO}_{2}$ fluxes and deviations of each field site from the mean across the soybean fields in central Iowa monitored on Day of the Year (DOY) 172 in 2002.

tion in $L E$ and precipitation was 0.78 . Deviations among fields from the average values were due to the rainfall patterns across the watershed. We observed a large increase in $L E$ in fields on the western portion of the watershed relative to the eastern portion following the precipitation event on DOY 185. Variation in rainfall patterns across a watershed can have a large effect on the energy balance observed among fields and, when these differences persist, can impact plant growth due to the availability of soil water.

Carbon dioxide fluxes during the initial growth period were small compared with later in the season when the crops achieved full ground cover and leaf area indices were $>4$. Leaf area differences among fields on DOY 189 are shown in Table 3. Growth progressions across the different fields showed a rapid increase during this period, from DOY 172 through 189, of almost 1.5 LAI units in corn and 0.6 LAI units in soybean (Anderson et al., 2004). The differences in $\mathrm{CO}_{2}$ fluxes from the average in both corn and soybean were directly related to the LAI of the canopy $(r=0.85)$. Variations among fields within the day were related to the deviations in
$Q^{*}$, of which solar radiation is the largest component during the daylight hours (Fig. 8e, 9e, 10e, and 11e).

\section{Cumulative Latent Heat and Carbon Dioxide Fluxes}

Differences among fields early in the season were relatively minor; however, during the season (DOY 166-231), cumulative $L E$ and $\mathrm{CO}_{2}$ fluxes began to show larger differences (Fig. 12 and 13). In the corn canopies, the cumulative difference in $L E$ ranged from 220 to $282 \mathrm{~mm}$ (Fig. 12a), while in the soybean the difference ranged from 200 to $230 \mathrm{~mm}$ (Fig. 13a). We have seen seasonal differences in soil water use within corn fields in this area of $300 \mathrm{~mm}$ (Hatfield and Prueger, 2001). Due to constraints for agronomic operations by the producers, the equipment was not able to be maintained in the fields for the entire growing season and the seasonal totals are reduced compared with a complete growing season. Differences in cumulative $L E$ are related to the total biomass and LAI of the crop. The seasonal differences in crop water use are related to the rainfall patterns 


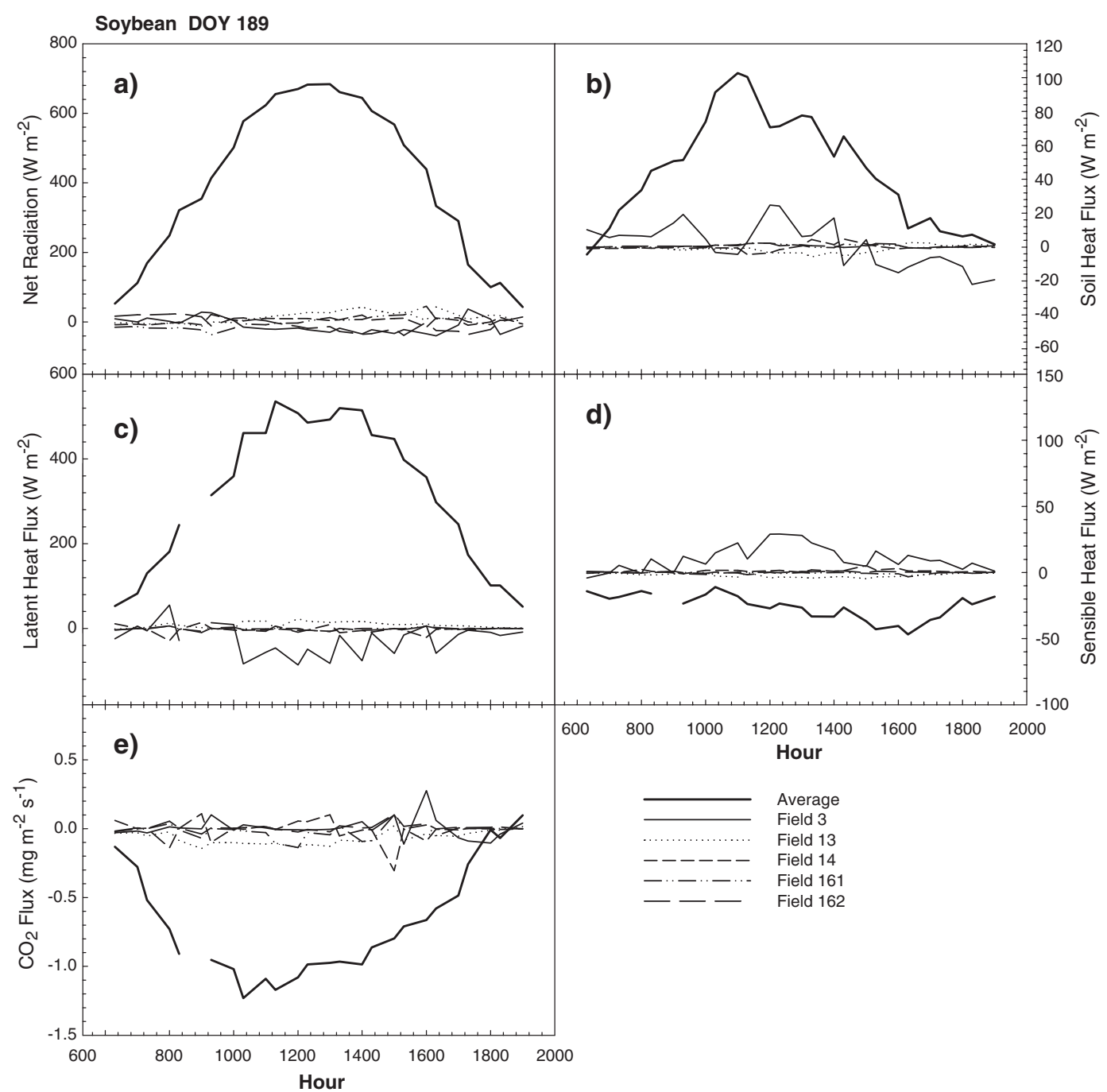

Fig. 11. Diurnal variation of average (a) net radiation, (b) soil heat flux, (c) latent heat, (d) sensible heat, and (e) $\mathrm{CO}_{2}$ fluxes and deviations of each field site from the mean across the soybean fields in central Iowa monitored on Day of the Year (DOY) 189 in 2002.

shown in Fig. 5 for the study area, where the western portion received more rainfall than the eastern sites. For example, Corn Site 25 was in the area of the watershed with drier soils, poor plant stands, and limited plant growth (Table 3; Fig. 5), while Site 6 was one of the wetter sites, with an more uniform plant population and better plant growth (Table 3 ). The biomass differences on DOY 189 were 900 vs. $600 \mathrm{~g} \mathrm{~m}^{-2}$ for Sites 6 and 25, respectively (Tables 1 and 3). Differences among the cumulative $L E$ values for soybean were quite small because these fields were very similar in their biomass and LAI (Table 3). Differences in $L E$ were related to differences in total crop biomass produced during portion of the season.

Fluxes of $\mathrm{CO}_{2}$ showed a similar trend to $L E$ with much more dramatic effect (Fig. 12b and 13b). In the corn fields, the cumulative difference ranged from 521 to $700 \mathrm{~g} \mathrm{~m}^{-2}$ (Fig. 12b). This difference was evident in the biomass produced in the different fields during this year. In the soybean fields, there was a smaller difference among the fields, with the range in the seasonal $\mathrm{CO}_{2}$ fluxes from 240 to $310 \mathrm{~g} \mathrm{~m}^{-2}$ (Fig. 13b). Cumulative $\mathrm{CO}_{2}$ uptake by corn or soybean canopies is related to the accumulation of biomass by the canopies, so the larger $\mathrm{CO}_{2}$ fluxes resulted in greater growth. The magnitude of the biomass differences between the corn and soybean canopies accounts for the differences in the magnitude of the values.

\section{CONCLUSIONS}

Spatial variations among corn and soybean fields within an area of central Iowa that is considered to be relatively uniform in appearance were due to three factors. Within a given day, spatial variation among sites was due to variation in cloud cover because of the presence of cumulus clouds. The variation among sites in $Q^{*}$ increased when the diurnal values deviated from a clear sky condition. Cumulus clouds across the study site were sufficient to cause differences in $Q^{*}$ values and this is particularly evident when the morning was clear and clouds formed in the afternoon (typical of DOY 172, Fig. 6 and 8). On days that immediately followed a rainfall event, the differences among sites were minimal be- 


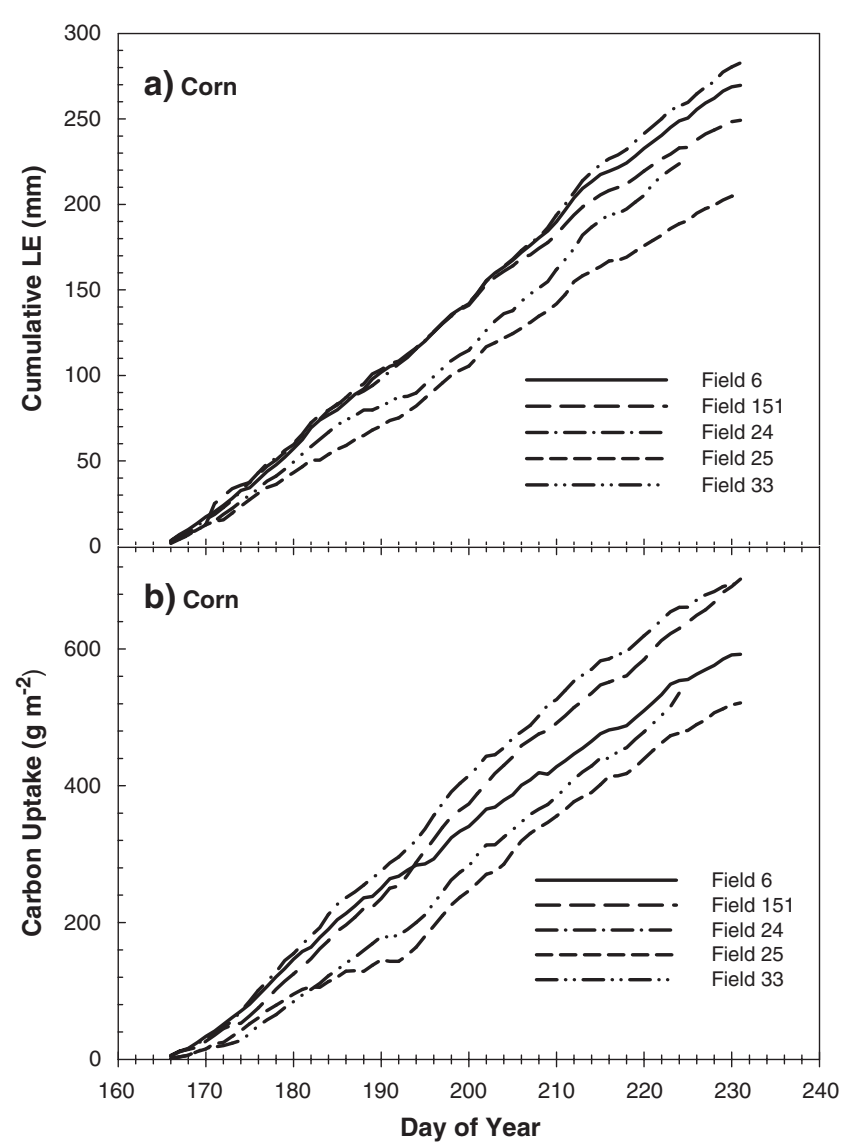

Fig. 12. Cumulative (a) latent heat and (b) $\mathrm{CO}_{2}$ fluxes for the corn fields measured in central Iowa during 2002 from Days of the Year (DOY) 166 through 231.

cause of the wetting of the soil surface (DOY 189) and the clear skies. Within the intensive study, variation in canopy growth among sites was related to the rate of change in ground cover and leaf area. These growth differences significantly affected $G, L E$, and $\mathrm{CO}_{2}$ uptake among the fields. During the growing season, differences in cumulative $L E$ fluxes and $C$ uptake across fields were related to the amount of rainfall received. The implications of these results would suggest that energy balance studies used to infer regional-scale fluxes should be interpreted with caution to ensure that the sites are represent of larger scale meteorological events, e.g., precipitation patterns. The differences we observed in this study are typical of what we have observed across similar soils within the same field (Hatfield and Prueger, 2001; Prueger et al., 2004). Understanding spatial variation in the energy balance and $\mathrm{CO}_{2}$ fluxes can increase our ability to quantify the potential impacts of changing land management practices on regional-scale hydrology and $\mathrm{C}$ balance.

\section{ACKNOWLEDGMENTS}

We express sincere appreciation for the efforts of Tim Hart and Forrest Goodman in establishing and operating the micrometeorological equipment. Without their diligence in this effort, this experiment would not be possible. The efforts by

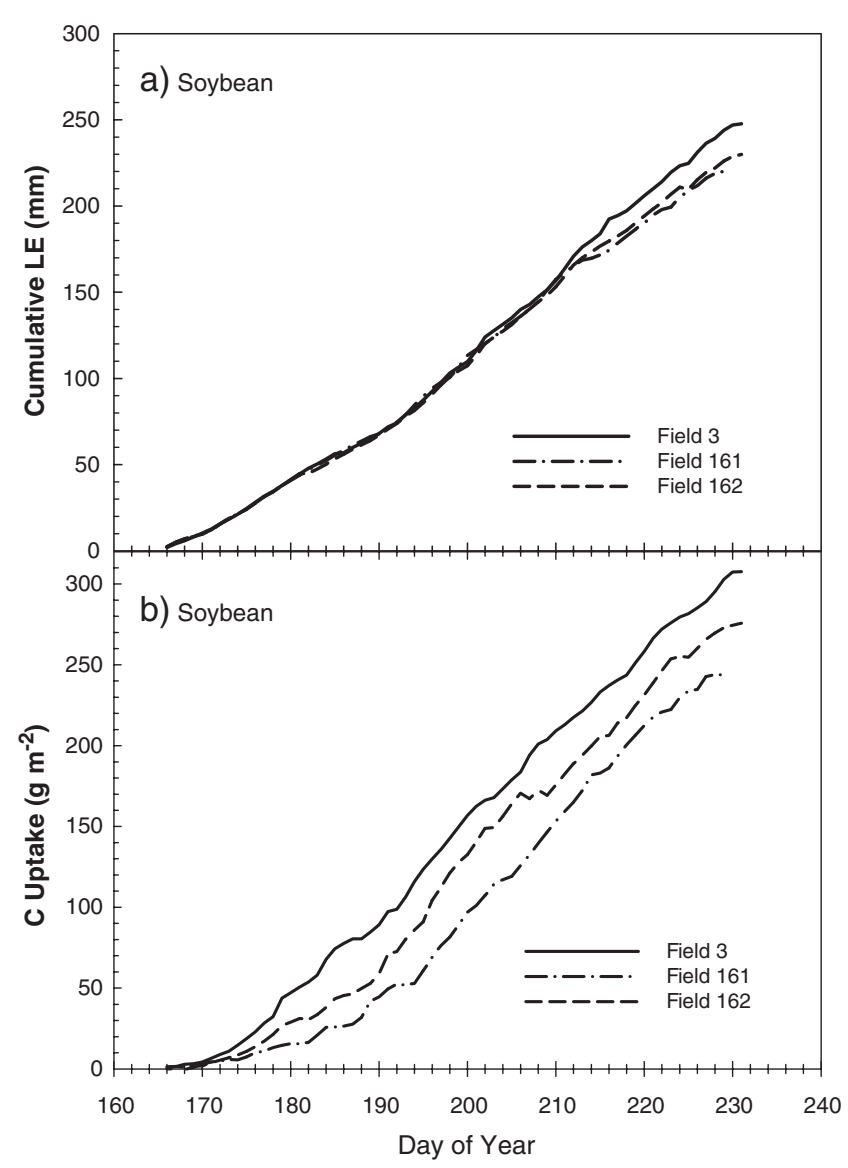

Fig. 13. Cumulative (a) latent heat and (b) $\mathrm{CO}_{2}$ fluxes for the soybean fields measured in central Iowa during 2002 from Days of the Year (DOY) 166 through 231.

Lynn McKee to provide the overall coordination for the data collection from the field sites in SMEX02 and produce a quality data set from the many volunteers are invaluable. We thank the many different scientists that provided equipment to this study to make this all possible.

\section{REFERENCES}

Anderson, M.C., C.M.U. Neale, F. Li, J.M. Norman, W.P. Kustas, H. Jayanthi, and J. Chavez. 2004. Upscaling ground observations of vegetation water content, canopy height, and leaf area index during SMEX02 using aircraft and Landsat imagery. Remote Sens. Environ. 92:447-464.

Arora, V.K. 2003. Simulating energy and carbon fluxes over winter wheat using coupled land surface and terrestrial ecosystem models. Agric. For. Meteorol. 118:21-47.

Baker, J.M., and T.J. Griffis. 2005. Examining strategies to improve the carbon balance of corn/soybean agriculture using eddy covariance and mass balance techniques. Agric. For. Meteorol. 128: 163-177.

Baldocchi, D.D. 1988. Measuring biosphere-atmosphere exchanges of biologically related gases with micrometeorological methods. Ecology 69:1331-1340.

Byre, K.R., J.M. Norman, L.G. Bundy, and S.T. Grower. 2000. Waterbudget evaluation of prairie and maize ecosystems. Soil Sci. Soc. Am. J. 64:715-724.

Farmer, D., M. Sivapalan, and C. Jothityangkoon. 2003. Climate, soil, and vegetation controls upon the variability of water balance in temperate and semiarid landscapes: Downward approach to water balance analysis. Water Resour. Res. 39(2):1035, doi:10.1029/ 2001WR000328. 
Ham, J.M., J.L. Heilman, and R.J. Lascano. 1991. Soil and canopy energy balances of a row crop at partial cover. Agron. J. 83:744-753.

Hatfield, J.L. 1989. Aerodynamic properties of partial canopies. Agric. For. Meteorol. 46:15-22.

Hatfield, J.L., D.B. Jaynes, M.R. Burkart, C.A. Cambardella, T.B. Moorman, J.H. Prueger, and M.A. Smith. 1999a. Water quality in Walnut Creek watershed: Setting and farming practices. J. Environ. Qual. 28:11-24.

Hatfield, J.L., and J.H. Prueger. 2001. Increasing nitrogen use efficiency of corn in midwestern cropping systems. Proc. Int. Nitrogen Conf. on Science and Policy, 2nd. Scientific World J. 1(Suppl. 2): 682-690.

Hatfield, J.L., J.H. Prueger, and D.W. Meek. 1999b. Spatial variation of rainfall over a large watershed in central Iowa. Theor. Appl. Climatol. 64:49-60.

Houghton, R.A. 1999. The annual net flux of carbon to the atmosphere from changes in land use 1850-1990. Tellus 51B:298-313.

Kustas, W.P., and J.D. Albertson. 2003. Effects of surface temperature on land atmosphere exchange: A case study from Monsoon 90. Water Resour. Res. 39(6):1159, doi:10.1029/2001WR001226.

Kustas, W.P., J.L. Hatfield, and J.H. Prueger. 2005. The Soil Moisture Atmosphere Coupling Experiment (SMACEX): Background, hydrometeorological conditions and preliminary findings. J. Hydrometeorol. 6:791-804.

Kustas, W.P., J.H. Prueger, J.L. Hatfield, J.I. MacPherson, M. Wolde, C.M.U. Neale, W.E. Eichinger, D.I. Cooper, J.M. Norman, and M. Anderson. 2003. An overview of the Soil-Moisture-AtmosphericCoupling-Experiment (SMACEX) in central Iowa. p. 1-5. In Proc. Conf. on Hydrol., 17th, Long Beach, CA [CD-ROM]. 9-13 Feb. 2003. Am. Meteorol. Soc., Boston.

Luxmoore, R.J., R.J. Millington, and D.B. Peters. 1973. Row crop microclimate. p. 377-388. In R.O. Slatyer (ed.) Plant response to climate factors. UNESCO, Paris.

Lyons, T.J., and S. Halldin. 2004. Surface heterogeneity and the spatial variation of fluxes. Agric. For. Meteorol. 121:153-165.

Meek, D.W., J.H. Prueger, W.P. Kustas, and J.L. Hatfield. 2005. Determining meaningful daily differences for SMACEX eddy covariance measurements. J. Hydrometeorol. 6:805-811.

Meyers, T.P., and S.E. Hollinger. 2004. An assessment of storage terms in the surface energy balance of maize and soybean. Agric. For. Meteorol. 125:105-115.

Prueger, J.H., J.L. Hatfield, T.B. Parkin, W.P. Kustas, and T.C. Kaspar. 2004. Carbon dioxide dynamics during a growing season in midwestern cropping systems. Environ. Manage. 33:S330-S343.

Small, E.E., and S.A. Kure. 2003. Tight coupling between soil moisture and the surface radiation budget in semiarid environments: Implications for land-atmosphere interactions. Water Resour. Res. 39(10):1278, doi:10.1029/2002WR001297.

Soegaard, H., N.O. Jensen, E. Boegh, C.B. Hasager, K. Schelde, and A. Thomsen. 2003. Carbon dioxide exchange over agricultural landscape using eddy correlation and footprint modeling. Agric. For. Meteorol. 114:135-173.

Soil Conservation Service. 1981. Soil survey of Boone County, Iowa. USDA-SCS, Washington, DC.

Soil Conservation Service. 1984. Soil Survey of Story County, Iowa. USDA-SCS, Washington, DC.

Walker, J.P., G.R. Willgoose, and J.D. Kalma. 2001. The Nerrigundah data set: Soil moisture patterns, soil characteristics, and hydrological flux measurements. Water Resour. Res. 37:2653-2658.

Webb, E.K., G.I. Pearman, and R. Leuning. 1980. Correction of flux measurements for density effects due to heat and water vapor transfer. Q. J. R. Meteorol. Soc. 106:85-100. 